\title{
DUFAN (DUNIA FANTASI) ANCOL DI ERA PANDEMI COVID-19 (DUFAN (DUNIA FANTASI) ANCOL IN PANDEMI COVID-19 ERA)
}

\author{
Dewi Ayu Kusumaningrum ${ }^{1}$, \\ Prodi Perhotelan, Politeknik Sahid \\ dewiayu@polteksahid.ac.id \\ Ramon Hurdawaty ${ }^{2}$ \\ Prodi Perhotelan, Politeknik Sahid \\ ramon.hurdawaty@polteksahid.ac.id
}

\begin{abstract}
The enactment of government policies to stop the spread of the virus, requires DUFAN to face new habitual adaptation situations by implementing health protocols, devising various strategies to ensure visitors even if limited movement can still have fun safely. This research discusses the adaptation efforts of tourist objects in the face of the COVID-19 pandemic. It is hoped that this research can become input in planning the adaptation of tourist destination. The qualitative research method used purposive sampling, the collection technique used triangulation (combined) and inductive data analysis. The results of the research are operational observation data of DUFAN, the obstacles faced and the perception of visitors in the pandemic era. DUFAN's operational activities conform to the Taman Impian Jaya Ancol policy. DUFAN's operational reopening was accompanied by various regulations; restrictions on visitors, online ticket reservations, check ticket and body temperature. Availability of hand sanitizer facilities and standing banner for health protocol regulations. There is a surveillance section that always goes around the entire DUFAN area and an environmental disinfection section. The implementation of the health protocol in the operation of game rides is carried out well, however, there are several obstacles faced. The main obstacle is the awareness of visitors about the importance of adhering to health protocols anytime anywhere in the DUFAN area smoking carelessly, not wearing a mask during activities in the DUFAN environment, violation of distance restrictions in queues. The perception of DUFAN visitors in the era of the COVID19 pandemic was quite good as assessed in terms of operational management systems, online ticket purchases, health protocol information, health protocols for visitors and tourist officers, availability of hand washing facilities, and safety of traveling in DUFAN. Visitors expect more tourist officers at DUFAN to patrol to remind visitors to apply health protocols, especially physical distancing.
\end{abstract}

Keywords: Pandemic; COVID-19; Tourism; Destination; DUFAN

\begin{abstract}
ABSTRAK
Pemberlakuan kebijakan pemerintah guna menghentikan penyebaran virus, mengharuskan DUFAN menghadapi situasi adaptasi kebiasaan baru dengan penerapan protokol kesehatan, membuat berbagai strategi untuk memastikan pengunjung walau gerak terbatas tetap dapat bersenang-senang dengan aman dan selamat. Penelitian ini membahas mengenai usaha
\end{abstract}


adaptasi objek wisata dalam menghadapi pandemi COVID-19. Diharapkan penelitian ini dapat menjadi bahan masukan dalam perencanaan adaptasi objek wisata dalam menghadapi pandemi COVID-19 dan menjadi langkah awal untuk penelitian selanjutnya. Metode penelitian kualitatif dengan pengambilan sampel secara purposive, teknik pengumpulan dengan trianggulasi (gabungan) dan analisis data secara induktif. Hasil penelitian berupa data observasi operasional DUFAN, kendala yang dihadapi serta persepsi pengunjung di era pandemi. Kegiatan operasional DUFAN menyesuaikan dengan kebijakan Taman Impian Jaya Ancol. Pembukaan kembali operasional DUFAN disertai dengan berbagai peraturan yang diterapkan pengelola berdasar pada kebijakan Pemerintah; pembatasan pengunjung, reservasi tiket hanya online melalui laman www.ancol.com. Pemeriksaan tiket dan suhu tubuh. Tersedianya fasilitas hand sanitizer dan standing banner peraturan protokol kesehatan. Terdapat bagian pengawasan yang selalu berkeliling ke seluruh wilayah DUFAN dan bagian desinfeksi lingkungan. Penerapan protokol kesehatan pada operasional wahana permainan dilakukan dengan baik namun terdapat beberapa kendala yang dihadapi. Kendala utama yaitu kesadaran pengunjung akan pentingnya menaati protokol kesehatan kapanpun dimanapun di wilayah DUFAN merokok sembarangan, tidak menggunakan masker selama berkegiatan di lingkungan DUFAN, pelanggaran pembatasan jarak dalam antrian. Persepsi pengunjung DUFAN di era pandemi COVID-19 cukup baik yang dinilai dari segi sistem pengelolaan operasional, pembelian tiket secara online, informasi protokol kesehatan, protokol kesehatan pengunjung dan petugas wisata, ketersediaan sarana cuci tangan, dan keamanan berwisata di DUFAN. Pengunjung mengharapkan petugas wisata di DUFAN lebih banyak lagi yang berpatroli untuk mengingatkan pengunjung menerapkan protokol kesehatan terutama physical distancing.

Kata Kunci: Pandemi; COVID-19; Pariwisata; Destinasi; DUFAN

Received: December 21, 2020/Reviewed: March 2, 2021/Published: July 25, 2021

\section{PENDAHULUAN}

Pandemi COVID-19 tidak hanya menjadi permasalahan kesehatan secara global, namun juga memengaruhi aspek ekonomi berkelanjutan yang berdampak pada aspek lainnya (Kusumaningrum et al., 2020), termasuk Indonesia yang mengalami kemunduran ekonomi dari semua bidang usaha. Badan Pusat Statistik (BPS) mengemukakan Indonesia resmi mengalami resesi pada kuartal III/2020 dan terjadi peningkatan tingkat pengangguran terbuka (TPT) dari 5,23 persen menjadi 7,07 persen (money.kompas.com, 2020). Salah satu sektor usaha yang sangat terpuruk adalah sektor usaha pariwisata. Pariwisata adalah sektor yang paling rentan terdampak, dengan 80\% Usaha Kecil Menengah (UKM) dan ribuan mata pencaharian di dalamnya (UNWTO, 2020).

Pariwisata merupakan rangkaian perjalanan wisata (tours/traveling) seseorang atau sekelompok orang kesuatu tempat untuk berlibur, menikmati keindahan alam dan budaya (sightseeing), bisnis, mengunjungi kawan atau kerabat, dan berbagai tujuan lainnya (Simanjuntak et al., 2018). Sedangkan daya tarik wisata merupakan suatu objek ciptaan Tuhan maupun hasil karya manusia, yang menarik minat orang untuk berkunjung dan menikmati keberadaannya (Yoeti, 2006). Industri pariwisata harus beradaptasi dan mulai berbenah untuk menyambut tatanan kehidupan baru atau new normal. Pariwisata Normal Baru diartikan sebagai adaptasi kebiasaan berwisata dengan cara yang diartikan sebagai kenormalan baru selama pandemi COVID-19. Di era new normal ini akan terjadi perubahan tren pariwisata, dimana destinasi pariwisata yang buka 
pada era ini harus menerapkan sejumlah aturan dan protokol kesehatan. Wisatawan harus menerapkan faktor kesehatan, kebersihan, keselamatan dan keamanan. Masyarakat yang tidak disiplin mengikuti protokol kesehatan bisa berdampak pada penyebaran virus ini yang semakin luas. Adaptasi kebiasaan baru dan kepatuhan masyarakat menjadi kunci agar risiko penyebaran rendah dan sektor pariwasata kembali bangkit.

Sektor pariwisata menjadi salah satu dari tiga sektor yang akan menjadi bisnis yang pertama kali bangkit (rebound) usai wabah COVID-19 berakhir di Indonesia, dimana masyarakat akan berwisata selepas pandemi ini berakhir (cnnindonesia.com, 2020). Pemerintah melalui Kementerian Pariwisata dan Ekonomi Kreatif (Kemenparekraf) mendorong tempat-tempat wisata yang berpotensi besar. Untuk membangkitkan pariwisata di Indonesia, pemerintah melakukan sejumlah strategi seperti sertifikasi cleanliness, health, safety (CHS) di destinasi wisata untuk meningkatkan kepercayaan wisatawan. Kemenparekraf memprioritaskan segmen wisatawan nusantara terlebih dahulu sebagai langkah awal pemulihan sektor pariwisata yang terdampak pandemi COVID-19.

Menurut WHO, negara/ wilayah yang akan menerapkan new normal paling tidak memenuhi beberapa persayaratan, yaitu 1) Negara yang menerapkan konsep new normal adalah negara yang memiliki bukti dapat mengendalikan penularan COVID-19, 2) Negara mampu melakukan identifikasi, isolasi, pengujian, pelacakan kontak, hingga melakukan karantina orang yang terinfeksi, 3) mampu menekankan resiko wabah virus COVID-19 untuk tempat yang memiliki resiko tinggi seperti di panti wreda, fasilitas kesehatan mental, serta kawasan pemukiman yang padat, 4) penetapan langkah-langkah pencegahan di lingkungan kerja, 5) mampu mengendalikan resiko terhadap kasus dari pembawa virus yang masuk ke suatu wilayah, 6) masyarakat harus diberikan kesempatan untuk memberi masukan, berpendapat dan dilibatkan dalam proses masa transisi menuju new normal (WTTC, 2020).

Sektor pariwisata sangat penting bagi perekonomian Indonesia karena merupakan sektor penyumbang devisa terbesar kedua setelah kelapa sawit (cnbcindonesia.com, 2019). Luasnya cakupan sektor pariwisata meliputi hotel, restoran, penerbangan, UMKM, dan sektor lain-lain yang terkait, sehingga menyerap tenaga kerja dan meningkatkan pendapatan ekonomi masyarakat. Keterpurukan pariwisata berdampak pula pada sektor pendukungnya. Seluruh usaha pariwisata di Indonesia mengalami keterpurukan, tak terkecuali objek wisata favorit di Jakarta yaitu DUFAN (Dunia Fantasi) yang terletak di kompleks Taman Impian Jaya Ancol.

Selama 35 tahun DUFAN bertahan sebagai kawasan terfavorit wisatawan di kompleks Taman Impian Jaya Ancol yang dikelola PT Pembangunan Jaya Ancol Tbk, seluas 21 hektare dengan 36 wahana bermain dapat dinikmati oleh seluruh anggota keluarga. Dunia Fantasi mencakup sembilan kawasan tematik dengan tema arsitektur bangunan hingga ornament unik, mulai dari Kawasan Hikayat, Indonesia, Eropa, Yunani, Jakarta, Asia, Amerika, Kidz Fantasy, dan Dunia Kartun (liputan6.com, 2020). Dampak pandemi pada DUFAN dan kompleks Taman Impian Jaya Ancol secara umum sangat merugikan. Per semester I/2020 PT Pembangunan Jaya Ancol Tbk sebagai pengelola DUFAN dan kompleks Taman Impian Jaya Ancol mengemukakan jumlah pengunjung menurun hingga $68,18 \%$ dibandingkan tahun sebelumnya, penurunan pendapatan sekitar 58\% dan mengalami kerugian sekitar 146 miliar (market.bisnis.com, 2020). Hal ini dikarenakan pemberlakuan kebijakan PSBB (Pembatasan Sosial Berskala Besar) Pemerintah Provinsi DKI Jakarta menutup tempat hiburan sejak Maret 2020 dan baru dibuka kembali pada 20 Juni 2020, kemudian diberlakukan kembali masa PSBB mulai 14 September 2020 sampai 12 Oktober 2020. Setelah itu, masuk masa PSBB transisi yang mengizinkan tempat hiburan dibuka dengan tetap menerapkan protokol kesehatan. 
Dalam menghadapi situasi adaptasi kebiasaan baru dengan penerapan protokol kesehatan, pengelola Taman Impian Jaya Ancol termasuk DUFAN membuat berbagai strategi program untuk memastikan pengunjung tetap dapat bersenang-senang dengan aman dan selamat. Salahsatunya membuat kampanye SSBB atau Senang Selamat Bareng bareng yang berisi berbagai peraturan bagi pengunjung (ancol.com, 2020). Tentu bukan hal mudah untuk mencapai keberhasilan dengan sesuatu yang baru, penerapan protokol kesehatan tentu akan membatasi gerak pengunjung sehingga perlu dipikirkan antisipasi ketidaknyamanan dengan berbagai strategi. Berdasarkan penelitian terbaru, persepsi wisatawan di era pandemi COVID-19 sekitar 78\% responden mengatakan akan kembali melakukan wisata dengan niat bepergian lebih tinggi daripada kecemasan dalam wisata di era pandemi (Wachyuni \& Kusumaningrum, 2020). Persepsi wisatawan akan mempengaruhi keputusan berwisata.

Menurut Young, Persepsi merupakan aktivitas mengindra, mengintegrasikan, serta memberikan penilaian pada objek-objek fisik ataupun sosial. Penginderaan tergantung dari stimulus fisik dan sosial di dalam lingkungannya. Faktor lingkungan ini berupa harapan, nilai, ingatan sikap dan lainnya (Wahyuningsih, 2018). Menurut Echols dan Shadily, Istilah persepsi berasal dari bahasa inggris perception yang dapat diartikan sebagai pengelihatan atau tanggapan daya memahami atau menanggapi. Dalam ilmu psikologi, persepsi merupakan proses transformasi stimulus lingkungan ke dalam pengalaman seseorang dimana proses tersebut diwujudkan dalam bentuk benda yang dapat dilihat dan disentuh, suara yang dapat didengar, aroma yang dibaui, peristiwa yang dapat yang dapat dilihat, dan lain-lain (Pratisti \& Yuwono, 2018). Walgito menyatakan persepsi adalah proses pengorganisasian, penginterpretasian terhadap stimulus yang diindera, sehingga dimengerti (bermakna) dan merupakan respons yang integrated dari individu (Pratisti, W. D \& Yuwono, S, 2018). Terdapat dua faktor yang mempengaruhi persepsi seseorang yaitu : 1) Faktor internal, terdiri dari Perasaan, sikap, dan kepribadian individu, keadaan fisik, prasangka, keinginan, atau harapan, perhatian (fokus), proses belajar, minat dan motivasi, nilai dan kebutuhan, 2) Faktor eksternal, terdiri dari Latar belakang keluarga, informasi yang diperoleh, pengetahuan dan kebutuhan sekitar, intensitas, ukuran, keberlawanan, pengulangan gerak, hal-hal baru dan familiar (Thoha, 2003).

Berdasarkan penelusuran peneliti, belum banyak penelitian yang membahas mengenai usaha adaptasi objek wisata secara khusus dalam menghadapi pandemi COVID-19. Terdapat beberapa peenlitian terkait persepsi konsumen tentang pariwisata di era normal baru, diantaranya adalah penelitian mendalam tentang Analisis Perilaku Konsumen Wisatawan Masa Pandemi COVID-19 (Studi Kasus Pariwisata di Nusa Tenggara Barat). Penelitian ini menggunakan metode pendekatan kualitatif untuk menganalisa perilaku konsumen, mengidentifikasi perilaku yang dapat merubah industri pariwisata mengerti akan kebutuhannya. Dari hasil analisa perilaku konsumen wisatawan di era pandemi COVID-19, dapat ditarik kesimpulan bahwa dengan memiliki pemahaman dan kepekaan yang baik terhadap motivasi wisatawan, produsen akan mudah untuk mengidentifikasi kebutuhan wisatawan yang ditunjukkan dengan keputusan pembelian sebagai gambaran perilaku konsumen (Suprihatin, 2020). Hasil penelitian tentang Pemulihan Ekonomi Pariwisata Bali di Era New Normal bahwa terjadinya pandemik COVID-19 hampir di seluruh dunia, mempengaruhi seluruh sektor kehidupan tak terkecuali Indonesia. Bali mengalami keterpurukan perekonomian, karena provinsi ini sangat mengandalkan kegiatan ekonomi dari sektor pariwisata. Diperlukan waktu yang lama untuk kembali meningkatkan ekonomi pariwisata Bali. Maka dari itu mulai 9 Juli pemerintah provinsi Bali menerapkan kebijakan New Normal. Kebijakan ini diterapkan bekerjasama dengan seluruh lini serta komponen masyarakat Bali seperti desa adat. Protokol Masyarakat Produktif dan Aman COVID-19 menuju normal baru (New 
Normal), hidup berdampingan dengan COVID-19 (Kristina, 2020). Hasil penelitian tentang New Normal bagi Pariwisata Bali di Era pandemi COVID-19 menjelaskan bahwa untuk mengetahui strategi pemulihan pariwisata Bali dalam new normal diantaranya, menerapkan standar kebersihan dan keamanan yang memadai bagi wisatawan, memberikan alternatif pola berwisata baru: staycation, niche tourism, solo travel tour, wellness tour, virtual tourism (Paramita \& Putra, 2020).

Penelitian ini secara kualitatif bertujuan mengetahui bagaimana DUFAN menjalankan usaha adaptasi wisata di era pandemi COVID-19, permasalahan yang dihadapi serta tanggapan pengunjung yang telah berkunjung di era pandemi COVID-19. Diharapkan penelitian ini dapat menjadi bahan masukan dalam perencanaan adaptasi objek wisata dalam menghadapi pandemi COVID-19 dan menjadi langkah awal untuk penelitian selanjutnya. Keterbatasan dalam studi ini adalah masih belum banyaknya penelitian pariwisata yang membahas tentang pariwisata di era pandemi COVID-19 yang dapat digunakan sebagai perbandingan dan keterbatasan interaksi langsung dengan narasumber terkait untuk wawancara mendalam dikarenakan kebijakan protokol kesehatan.

\section{METODOLOGI PENELITIAN}

Penelitian ini merupakan penelitian kualitatif yang menggambarkan general fenomena yang terjadi dengan peneliti sebagai instrument kunci, sampel didapatkan dengan metode purposive, teknik pengumpulan dengan trianggulasi (gabungan) dan analisis data secara induktif (Anggito \& Setiawan, 2018). Dalam penelitian ini fenomena yang dimaksudkan adalah pandemi COVID-19 yang terjadi secara global sejak Maret 2020. Objek penelitian adalah DUFAN (Dunia Fantasi) kawasan wahana bermain di kompleks Taman Impian Jaya Ancol dan pengunjung DUFAN yang merasakan dampak selama pandemi COVID-19. Hal ini sesuai dengan tujuan penelitian kualitatif untuk memahami secara general fenomena dari sudut pandang partisipan, konteks sosial dan institusional (Anggito \& Setiawan, 2018). Pengumpulan data dilakukan dengan wawancara terhadap pengelola dan pengunjung DUFAN, observasi partisipasi peneliti ke DUFAN di bulan Desember 2020 serta penelusuran pustaka dari jurnal penelitian, artikel media massa, serta sumber data lainnya. Pada observasi partisipasi, peneliti menggunakan alat yang digunakan untuk membantu peneliti dalam mencatat hasil observasi partisipasi dapat berbentuk fieldnote atau catatan lapangan, dokumentasi foto (Rachmawati, 2017). Analisis data kualitatif mengintepretasi keseluruhan data yang ada dengan mengubah atau menerjemahkan data mentah ke dalam bentuk uraian atau deskripsi dan eksplanasi dari fenomena yang sedang diteliti, dilakukan melalui tiga tahap atau proses yakni reduksi data (data reduction), pengorganisasian (organisation), dan interpretasi data (interpretation) (Junaid, 2018).

\section{HASIL DAN PEMBAHASAAN}

Berdasarkan observasi peneliti langsung ke objek penelitian serta wawancara terhadap manajemen pengelola, karyawan serta pengunjung DUFAN, pembahasan terbagi menjadi tiga bagian yaitu pembahasan operasional wahana bermain Dunia Fantasi (DUFAN) di era pandemi COVID-19, kendala yang dihadapi dan persepsi pengunjung DUFAN di era pandemi COVID-19.

\section{Operasional Dunia Fantasi (DUFAN)}

Dunia Fantasi (DUFAN) merupakan kawasan wahana bermain di kompleks Taman Impian Jaya Ancol yang dikelola PT Pembangunan Jaya Ancol Tbk. Untuk kegiatan operasional DUFAN menyesuaikan dengan kebijakan Taman Impian Jaya Ancol yang didalamnya mencakup DUFAN, SeaWorld dan lainnya mengikuti kebijakan dengan menutup operasional. Kebijakan PSBB 
(Pembatasan Sosial Berskala Besar) oleh Pemerintah Provinsi DKI Jakarta pada April 2020 menutup sementara fasilitas umum dan objek wisata, termasuk Taman Impian Jaya Ancol. Kebijakan penutupan berakhir pada 19 Juni 2020, dan siap dibuka esok harinya. Namun, seiring dengan meningkatnya kasus positif COVID-19 di Jakarta, pemerintah memberlakukan kembali PSBB yang menutup kembali seluruh fasilitas umum dan tempat wisata termasuk DUFAN pada 14 September 2020 sampai dibuka kembali pada 12 Oktober 2020.

Selama masa penutupan, Manajemen operasional Ancol mencari cara untuk mengatasi kondisi penutupan namun tetap dapat menghasilkan pendapatan. Antara lain menawarkan layanan tur virtual, salah satunya melalui Instagram Live. Layanan tur virtual dengan judul "Acara Liburan Virtual Ancol Taman Impian" menyuguhkan hiburan yang bisa diakses oleh kalangan manapun melalui akun media sosial unit Ancol (travel.kompas.com, 2020). Terdapat juga wisata edukasi virtual dengan konsep pembelajaran jarak jauh. Wisata edukasi virtual ini merupakan kolaborasi dengan Sekolah.mu. Manajemen Ancol menawarkan pengalaman pembelajaran interaktif berbalut kegembiraan atau edutainment (education-entertainment) yang mencangkup unit-unit rekreasi Ancol yaitu Dunia Fantasi, Sea World Ancol, dan Ocean Dream Samudra. Paket wisata edukasi virtual ini dibanderol Rp 400.000 per paket dan juga bisa digunakan untuk akses tiket masuk DUFAN, Sea World, atau Ocean Dream Samudra hingga 30 Juni 2021. Selain itu, ditawarkan aktivitas wisata secara virtual yang berkolaborasi dengan 360 Indonesia yang merupakan perusahaan pembuat konten 360 photo dan video. Untuk bisa menikmati virtual tour keliling Ancol dengan mengunjungi situs www.ancol.com atau langsung klik https://www.ancol.com/rekreasi-virtual (megapolitan.kompas.com, 2020). Manajemen sumbar daya karyawan melakukan pola kerja Work from Home (WFH) dan Work from Office (WFO) dimana sekitar $82 \%$ karyawan melakukan pola kerja WFH. Sisanya tetap melakukan pola kerja WFO terutama untuk pemeliharaan dan pengamanan dengan tetap menerapkan protokol kesehatan seperti pemeriksaan suhu tubuh, penggunaan masker serta penerapan physical distancing antar karyawan. Hal ini masih berlaku saat pembukaan kembali Taman Impian Jaya Ancol.

Pembukaan kembali operasional DUFAN disertai dengan berbagai peraturan yang diterapkan pengelola berdasar pada kebijakan Pemerintah. Serta kebijakan protokol kesehatan. Berdasarkan Keputusan Menteri Kesehatan nomor HK.01.07/MENKES/382/2020 tentang Protokol Kesehatan bagi Masyarakat di Tempat dan Fasilitas Umum yang disahkan pada 19 Juni 2020, tempat dan fasilitas umum yang dimaksud dalam Keputusan Menteri Kesehatan termasuk objek wisata (Kemenkes, 2020). Kebijakan protokol kesehatan di tempat atau fasilitas umum wajib diterapkan oleh semua pihak di objek wisata baik pihak pengelola atau penyelenggara, pekerja, dan pengunjung. Karena risiko pergerakan orang dan berkumpulnya masyarakat pada tempat dan fasilitas umum, memiliki potensi penularan COVID-19 yang cukup besar. Berbagai peraturan baru diterapkan oleh manajemen operasional DUFAN disesuaikan dengan kebijakan pemerintah, agar tetap dapat menerima pengunjung dengan aman. Berdasarkan informasi manajemen pengelola, setiap harinya DUFAN menerima sekitar 5000 pengunjung, angka ini masih dibawah target 10.000 pengunjung per hari.

Peraturan jam buka operasional yang berubah menjadi mulai pukul 10.00-17.00 WIB. Sedangkan pintu gerbang Ancol mulai beroperasi pukul 06.00-18.00 WIB. Peraturan terkait pengunjung yang diterapkan pengelola DUFAN yaitu pembatasan pengunjung sebanyak 50 persen dari kapasitas normal. Pengunjung yang diizinkan masuk harus memiliki KTP berdomisili DKI Jakarta dan usia dibatasi 9 tahun ke atas sesuai dengan aturan Taman Impian Jaya Ancol (TIJA), pengunjung yang diperbolehkan masuk ke DUFAN hanya warga berdomisili di DKI 
Jakarta. Pada awal pemberlakuan ketentuan PSBB dilakukan pengecekan kelengkapan kartu identitas, seperti KTP saat memasuki pintu gerbang Ancol. Pengunjung yang memiliki identitas domisili di luar DKI Jakarta tidak diizinkan untuk masuk kawasan Ancol. Namun, seiring berjalannya waktu pengecekan kelengkapan kartu identitas tidak lagi dilakukan. Hal ini juga terjadi pada ketentuan pelarangan golongan usia yang masuk ke DUFAN, seperti anak di bawah usia sembilan tahun, orang lanjut usia (lansia) yang berumur di atas 50 tahun, serta ibu yang sedang mengandung atau hamil. Saat peneliti melakukan observasi tidak lagi diberlakukan secara ketat. Menurut pengelola, hal itu sebatas anjuran bukan peraturan mengikat.

Ketentuan lain terkait pembelian tiket, pengunjung hanya bisa membeli tiket secara online. Pengunjung diharuskan membeli atau reservasi tiket melalui laman www.ancol.com. Cara awal membuka laman website www.ancol.com dan klik menu tiket, pilih tipe tiket dan unit rekreasi yang dituju, pilih tanggal reservasi kunjungan jika kuota tersedia tanggal tersebut bisa dipilih dan bila kuota telah habis maka bisa memilih tanggal lainnya. Pembelian tiket sudah mencakup tiket Gerbang Ancol dan unit rekreasi. Jika pengunjung membawa kendaraan, maka wajib membeli tiket kendaraan di halaman tiket tersebut. Untuk hari biasa yakni Senin sampai Jumat, tiket DUFAN bisa dibeli melalui situs resmi Ancol seharga Rp 225.000 untuk satu kali kunjungan. Sedangkan untuk akhir pekan dan hari libur lainnya, tiket bisa dibeli dengan harga Rp 275.000. Setelah itu lakukan konfirmasi pembelian dan mengisi informasi tambahan tempat tinggal dan provinsi guna contact tracing. Kemudian, check out dan pilih metode pembayaran. Tahap akhir, cek kembali pemesanan dan lakukan pembayaran sesuai metode yang dipilih. Setelah pembayaran berhasil, tiket atau e-voucher akan dikirim melalui alamat email yang digunakan untuk memesan tiket.

Pengunjung yang datang akan diperiksa terlebih dahulu tiket online yang dimiliki di gerbang depan DUFAN. Setelah divalidasi, pengunjung akan dicek suhu tubuhnya, jika lebih dari 37,3 derajat Celcius, maka tidak diizinkan masuk. Setelah melewati gerbang depan, diberlakukan antrian sebelum memasuki pintu masuk DUFAN (Gambar 1)
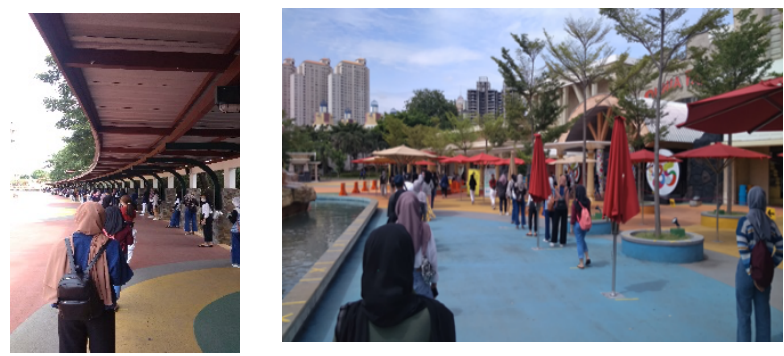

Gambar 1. Antrian sebelum memasuki pintu masuk DUFAN Sumber : Dokumentasi pribadi, 2020

Pada pintu masuk DUFAN dilakukan pengecekan barang bawaan pengunjung. Kemudian, pengunjung akan melalui proses pengecekan tiket DUFAN, dan petugas akan memvalidasi barcode tiket online yang dimiliki (Gambar 2). 


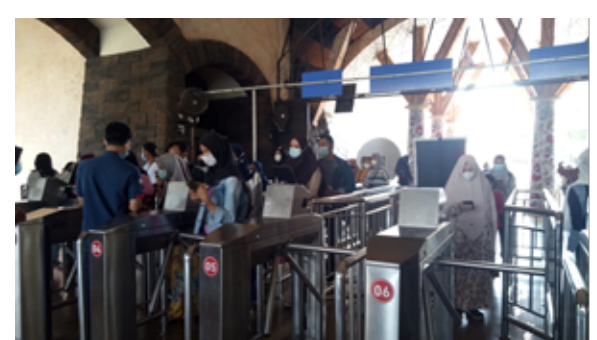

Gambar 2. Pengecekan tiket di pintu masuk DUFAN Sumber : Dokumentasi pribadi, 2020

Terdapat hal yang cukup berbeda dibanding dengan sebelum pandemi, yaitu pengunjung diperbolehkan membawa makanan dan peralatan makan dari luar, hal ini dikarenakan DUFAN belum membuka banyak kedai makanan dan hanya ada beberapa kedai yang menjual minuman. Hal ini salah satu cara untuk meminimalisir risiko penyebaran COVID-19. Setelah masuk pintu masuk, pengunjung akan diminta untuk mencuci tangan atau menyemprotkan hand sanitizer terlebih dahulu yang tersedia di pintu masuk (Gambar 3).

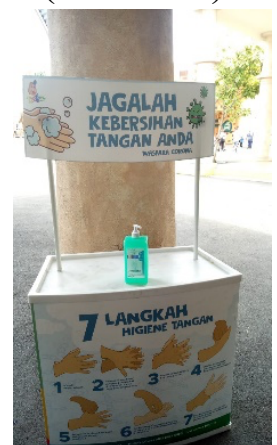

Gambar 3. Fasilitas hand sanitizer

Sumber : Dokumentasi pribadi, 2020

Kemudian pengunjung dapat memulai petualangan bermain wahana di DUFAN. Di beberapa tempat, fasilitas hand sanitizer cukup tersedia dan juga standing banner yang berisikan peraturan protokol kesehatan yang wajib dipatuhi pengunjung (Gambar 4).

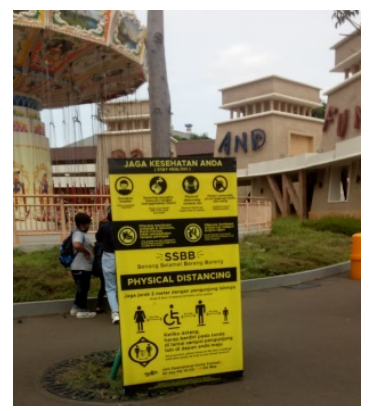

Gambar 4. Standing banner peraturan protokol kesehatan Sumber : Dokumentasi pribadi, 2020

Fasilitas umum seperti tempat duduk, toilet dan tempat ibadah serta beberapa kedai makanan yang buka, sudah memenuhi ketentuan protokol kesehatan yang dipersyaratkan. Memberikan standing banner informasi penggunaan fasilitas, tanda jaga jarak dan kontak fisik, tanda silang di 
kursi, titik berdiri, serta garis antri pada setiap tempat bagi pengunjung, membuat jarak dalam penggunaan fasilitas umum (Gambar 5).
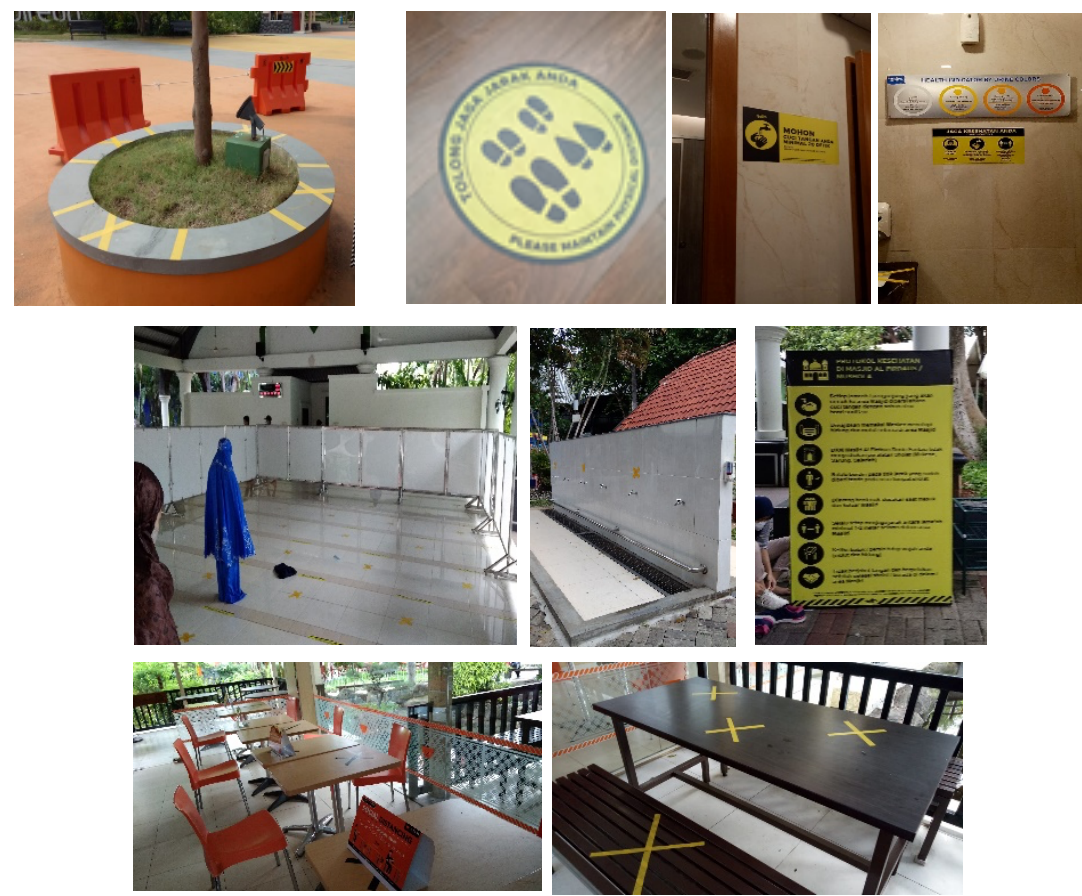

Gambar 5. Tempat duduk, toilet dan tempat ibadah serta beberapa kedai makanan Sumber : Dokumentasi pribadi, 2020

Selain fasilitas umum, manajemen operasional memperhatikan operasional wahana permainan untuk disiplin menerapkan protokol kesehatan dalam kegiatan operasional. Selain mengurangi anggaran pengeluaran, manajemen memaksimalkan sejumlah karyawan melakukan beberapa tugas dalam satu waktu, mengingat waktu operasional yang berkurang serta pengunjung yang juga berkurang. Adanya pengurangan karyawan yang bertugas setiap harinya, hanya sekitar 20 karyawan dalam sehari bertugas disebar diseluruh wahana permainan dan bagian pengawasan serta desinfeksi lingkungan. Berdasarkan wawancara terhadap salah satu karyawan, disebutkan terdapat pengurangan karyawan. Bagi karyawan yang masih dipekerjakan pun mengalami pengurangan jam kerja. Saat ini, pada satu wahana permainan dijaga oleh sekitar 2 karyawan yang bertugas mengoperasikan mesin permainan dan mengatur antrian pengunjung sembari menyemprotkan hand sanitizer dan berjalan berkeliling antrian mengingatkan protokol kesehatan. Bagian pengawasan yang selalu berkeliling ke seluruh wilayah DUFAN membawa pengeras suara mengingatkan pengunjung akan protokol kesehatan serta bagian desinfeksi lingkungan yang berkeliling ke seluruh wahana permainan menyemprotkan desinfektan sekali dalam sehari yang dilakukan pula oleh karyawan yang saat itu sedang dalam jadwal shift kerja (Gambar 6) 

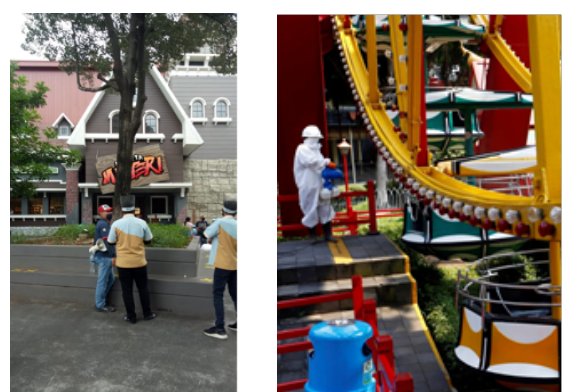

Gambar 6. Petugas pengawasan dan desinfeksi lingkungan

Sumber : Dokumentasi pribadi, 2020 dan Kumparan.com, 2020

Beroperasinya kembali DUFAN dilakukan secara bertahap, tidak semua wahana permainan dioperasikan, khususnya wahana indoor seperti Ice Age, Games Station, Shooting Gallery dinonaktifkan sementara demi menghindari penyebaran virus. Hal ini berdasarkan peraturan pemerintah potensi kegiatan indoor lebih tinggi. Sementara hanya 20 wahana yang beroperasi. Pengunjung dapat lebih jelas melihat informasi wahan permainan berikut jam buka di papan informasi di area DUFAN yang tersedia di beberapa tempat. Penerapan protokol kesehatan pada operasional wahana permaianan dilakukan dengan baik seperti pada setiap wahana selalu diterapkan jarak antar antrian, ada garis antrian, batas jarak tempat duduk, terdapat petugas yang menyemprotkan hand sanitizer sebelum memasuki area permainan (Gambar 7).

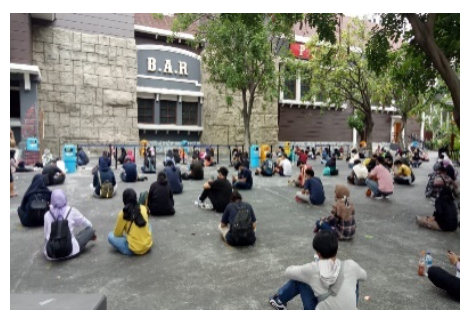

Gambar 7. Pelaksanaan protokol kesehatan
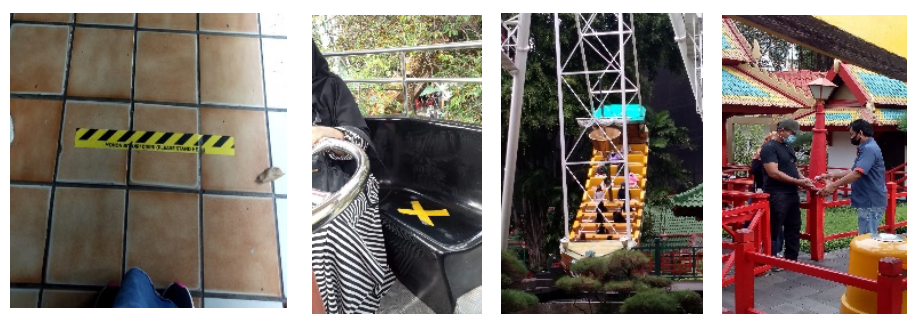

Sumber : Dokumentasi pribadi, 2020

\section{Kendala Yang Dihadapi}

Berdasarkan observasi peneliti langsung pada objek penelitian, pelaksanaan penerapan protocol kesehatan sudah dilakukan dengan baik oleh karyawan operasional namun terdapat beberapa kendala yang dihadapi. Kendala utama yaitu kesadaran pengunjung akan pentingnya menaati protokol kesehatan kapanpun dimanapun di wilayah DUFAN. Pengunjung tidak mengindahkan peraturan dengan merokok sembarangan, tidak menggunakan masker selama berkegiatan di lingkungan DUFAN, pelanggaran pembatasan jarak dalam antrian, petugas wahana harus selalu berkeliling mengingatkan bahkan sampai berteriak untuk memperingatkan pengunjung untuk menjaga jarak antar satu dengan lainnya dalam antrian (Gambar 8). 

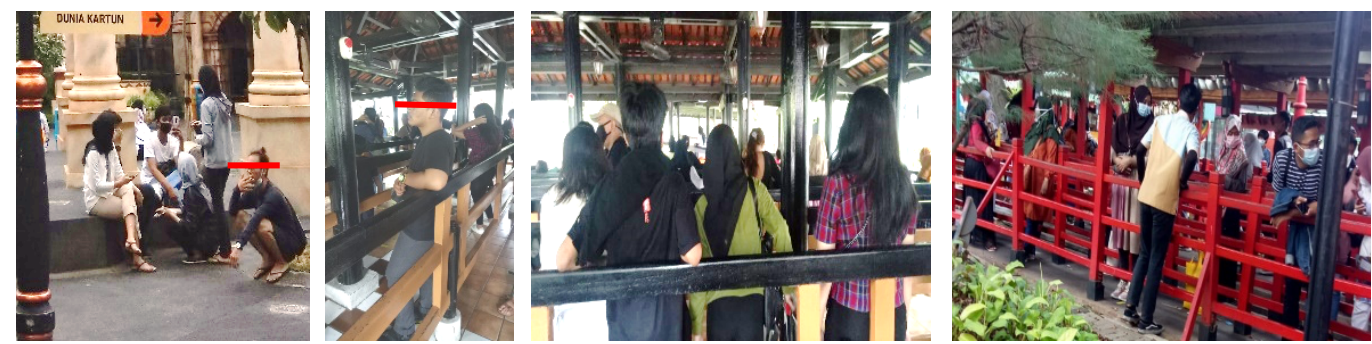

Gambar 8. Pelanggaran penerapan protokol kesehatan

Sumber : Dokumentasi pribadi, 2020

\section{Persepsi Pengunjung DUFAN di Era Pandemi COVID-19}

Informan penelitian ini terdiri dari 10 informan yaitu wisatawan yang berkunjung ke DUFAN dalam kurun waktu pandemi COVID-19.

Peneliti membahas hasil penelitian dari hasil wawancara dengan informan mengenai persepsi pengunjung Dunia Fantasi (DUFAN) Ancol di era pandemi COVID-19. Persepsi masyarakat menurut Husky merupakan proses inderawi seseorang yang menjadikan sadar akan yang terdapat di lingkungan sekitarnya dan kesadaran setiap individu atau orang berbeda dalam cara melihat serta apa yang dilihat orang lain (Munawaroh et al., 2018). Sedangkan menurut Pitana \& Diatra pengelolaan pariwisata haruslah mengacu pada prinsip-prinsip pengelolaan yang menekankan nilai-nilai kelestarian lingkungan alam, komunitas, dan nilai sosial yang memungkinkan wisatawan menikmati kegiatan wisatanya serta bermanfaat bagi kesejahteraan komunitas lokal (Pitana \& Diarta, 2009).

Pengalaman masa lalu dapat mempengaruhi persepsi seseorang karena manusia akan menarik kesimpulan yang sama dengan apa yang dilihat, dengar dan rasakan. Dalam membuat suatu keputusan dapat dipengaruhi oleh faktor keinginan. Biasanya seseorang dapat menolak tawaran yang tidak sesuai dengan apa yang dilihat. Selain itu mendengarkan cerita pengalaman yang telah dialami oleh orang lain juga dapat mempengaruhi mempengaruhi persepsi seseorang.

\section{Persepsi pengunjung mengenai sistem pengelolaan operasional DUFAN di era pandemi COVID-19}

Dari hasil wawancara, pengunjung Dunia Fantasi di era pandemi yang berkunjung pada bulan Agustus - November 2020, terdapat berbagai persepsi mengenai aktifnya kembali objek wisata DUFAN tersebut. Persepsi pengunjung mengenai sistem pengelolaan operasional DUFAN di era pandemi COVID-19 rata-rata informan berpendapat cukup baik, namun menurut informan ke-4 masih kurang dalam sosial distancing. Menurut informan ke-5, DUFAN banyak memberikan promo tetapi wahana bermain banyak yang tidak beroperasi sehingga informan merasa kurang puas.

Sejak awal DUFAN dibuka kembali pada era pandemi, pihak manajemen DUFAN menerapkan protokol kesehatan untuk kenyamanan pengunjung, antara lain :
a. Pembatasan jumlah pengunjung DUFAN, yaitu 25 persen dari kapasitas normal
b. Pengunjung usia di bawah 9 tahun diperbolehkan masuk dengan pendampingan
c. Tidak ada penjualan tiket secara fisik di loket DUFAN, tiket hanya dijual secara online
d. Semua transaksi di kawasan DUFAN berupa Cashless (tanpa uang tunai)
e. Pemeriksaan ketat di pintu masuk DUFAN (pengecekan tiket online, suhu tubuh, barang bawaan)
f. Pengunjung wajib menggunakan masker yang menutupi hidung dan mulut 
g. Pengunjung harus menjaga jarak dengan pengunjung lain

h. Pengunjung diharapkan membawa kebutuhan pribadi sendiri (alat makan, alat solat, hand sanitizer)

i. Jam operasional DUFAN adalah pukul $10.00-17.00 \mathrm{WIB}$

j. Tidak semua wahana DUFAN beroperasi

k. Kursi wahana dibatasi (batas jarak tempat duduk)

\section{Persepsi pengunjung mengenai pembelian tiket masuk DUFAN secara online}

Menurut beberapa informan merasa mudah dengan sistem pembelian tiket secara online. Namun menurut informan ke-5 merasa agak kesulitan dalam proses pembelian tiket online karena belum terbiasa. Semua objek wisata di Ancol termasuk DUFAN menerapkan pembelian tiket secara online per 13 Juni 2020, sehingga pembelian tiket secara fisik tidak ada lagi. Pengunjung dapat memilih sesuai tanggal kedatangan dan tiket hanya berlaku di tanggal tersebut.

\section{Persepsi pengunjung mengenai informasi tentang protokol kesehatan di DUFAN}

Menurut Informan ke-1 cukup banyak informasi protokol kesehatan seperti spanduk dan adanya imbauan melalui pengeras suara. Menurut informan ke-2, informasi protokol kesehatan cukup banyak. Menurut informan ke-3, sangat banyak informasi tentang protokol kesehatan. Namun menurut informan ke-4 (Irawan) informasi protokol kesehatan pengunjung masih kurang, contohnya pada saat proses antrian di wahana bermain. Begitu juga, menurut pendapat informan ke-5 mengungkapkan penyampaian informasi protokol kesehatan di DUFAN belum terlalu banyak dan kurang diberlakukan secara ketat. Berbeda dengan persepsi informan ke-6, 7, 8, 9 dan 10, yang merasa menerima informasi protokol kesehatan di DUFAN sudah baik dan banyak.

Saat ini manajemen DUFAN memperhatikan pedoman protokol kesehatan sebagaimana yang ditetapkan oleh pemerintah. Terdapat papan infomrasi yang membantu menginformasikan para pengunjung terkait protokol kesehatan, serta terdapat marka lantai penanda untuk membantu menginformasikan jarak fisik yang tepat saat antrian di wahana. Pihak manajemen juga melatih para petugas untuk membantu mensosialisasikan dan menghimbau secara langsung maupun melalui pengeras suara terkait jarak fisik di kawasan DUFAN maupun pada saat antrian.

\section{Persepsi pengunjung mengenai protokol kesehatan pengunjung DUFAN} (pengecekan suhu, wajib menggunakan masker dan physical distancing)

Menurut informan ke-1 mengenai penerapan protokol kesehatan pengunjung DUFAN sudah cukup baik, namun hanya physical distancing yang masih kurang diterapkan di DUFAN. Menurut informan ke-2, ke-3 , ke-5 , ke-6, ke-7, ke-8, ke-9, ke-10 , penerapan protokol kesehatan di DUFAN sudah baik. Sedangkan menurut informan ke-4, penerapan protokol kesehatan hanya pada awal masuk DUFAN saja, setelah berada di dalam DUFAN penerapannya masih kurang.

Seluruh kawasan rekreasi Ancol khususnya DUFAN menerapkan protokol kesehatan seperti pemeriksaan suhu tubuh. Apabila terdapat pengunjung dengan suhu badan di atas $37.3{ }^{\circ} \mathrm{C}$ tidak dizinkan untuk memasuki kawasan Ancol. Pengunjung juga diwajibkan mengenakan masker selama berada di kawasan DUFAN. Selain itu diharapkan untuk membawa peralatan ibadah, peralatan makan dan minum sendiri untuk mencegah penyebaran virus COVID-19.

\section{Persepsi pengunjung mengenai ketersediaan sarana cuci tangan di DUFAN}

Rata-rata persepsi dari informan menanggapi ketersediaan tempat cuci tangan di DUFAN sudah memadai. Namun menurut infoman ke-4 ketersediaan tempat cuci tangan masih kurang 
banyak. Begitu juga menurut informan ke-5, untuk tempat cuci tangan di DUFAN hanya ada di toilet saja. Informasi dari pihak Manajemen DUFAN berkomitmen untuk fokus meningkatkan hygiene dan sanitasi dengan penambahan fasilitas cuci tangan dan melalukan penyemprotan dengan desinfektan secara berkala diseluruh kawasan DUFAN.

\section{Persepsi pengunjung mengenai Protokol kesehatan yang dilaksanakan oleh petugas wisata DUFAN}

Persepsi informan yang melihat langsung di tempat wisata, pelaksanaan protokol kesehatan oleh petugas wisata di DUFAN sudah cukup baik dengan semua karyawan selalu memakai masker, bekerja dalam jarak kerja yang berjauhan. Pihak manajemen DUFAN mewajibkan seluruh petugas wisata dan karyawan operasional menerapkan protokol kesehatan dan keselamatan untuk dapat memberikan rasa aman, selamat dan nyaman kepada pengunjung.

\section{Persepsi pengunjung mengenai keamanan berwisata di DUFAN}

Semua informan merasa aman saat berwisata di DUFAN selama jumlah pengunjung masih dibatasi dan menerapkan protokol kesehatan dengan baik. Manajemen Ancol khususnya DUFAN berkomitmen memberikan rasa aman dan selamat kepada pengunjung dengan menerapkan protokol kesehatan dengan baik sesuai dengan aturan dari Gugus Tugas Percepatan Penanganan COVID-19, Badan Nasional Penanggulangan Bencana (BNPB), Kementrian Kesehatan Republik Indonesia, Dinas Kesehatan PemProv DKI Jakarta dan lembaga pemerintah yang sesuai.

Dari hasil wawancara dengan pengunjung DUFAN di era New Normal, terdapat beberapa saran dan masukan secara keseluruhan terhadap pengelolaan objek wisata DUFAN saat New Normal, yaitu :

1. Physical distancing agar diperketat, dikarenakan banyak pengunjung yang mengantri namun tidak jaga jarak.

2. Petugas wisata di DUFAN agar dapat mengingatkan pengunjung untuk tetap menerapkan protokol kesehatan (memakai masker, mencuci tangan setelah bermain wahana, menerapkan physical distancing) dan lebih banyak petugas yang berpatroli.

3. Wahana di DUFAN diharapkan lebih banyak dibuka agar tidak terjadi antrian panjang

4. Ketersediaan sarana cuci tangan harus diperbanyak

5. Antrian wahana harus dibatasi untuk menerapkan physical distancing

\section{SIMPULAN}

Dampak pandemi COVID-19 meluas, terutama usaha pariwisata di Indonesia mengalami keterpurukan, tak terkecuali objek wisata favorit Jakarta yaitu wahana bermain DUFAN (Dunia Fantasi). Pemberlakuan kebijakan PSBB (Pembatasan Sosial Berskala Besar) Pemerintah Provinsi DKI Jakarta, mengharuskan DUFAN menghadapi situasi adaptasi kebiasaan baru dengan penerapan protokol kesehatan, membuat berbagai strategi program untuk memastikan pengunjung tetap dapat bersenang-senang dengan aman dan selamat. Penerapan protokol kesehatan tentu akan membatasi gerak pengunjung sehingga perlu dipikirkan antisipasi ketidaknyamanan dengan berbagai strategi usaha adaptasi.

Berdasarkan tujuan penelitian dapat disimpulkan usaha adaptasi objek wisata DUFAN sudah cukup baik dilakukan, melihat dari upaya manajemen dalam operasional mengutamakan penerapan kebijakan serta tanggapan baik pengunjung yang menyatakan tetap dapat berwisata 
walau dengan keterbatasan. Kegiatan operasional di era pandemi COVID-19 menyesuaikan dengan kebijakan Taman Impian Jaya Ancol. Selama awal masa penutupan, ditawarkan layanan tur virtual. Kemudian dengan pembukaan kembali operasional DUFAN disertai dengan berbagai peraturan yang diterapkan pengelola berdasar pada kebijakan Pemerintah. Pembatasan pengunjung sebanyak 50 persen, hanya pengunjung pemilik KTP berdomisili DKI Jakarta dan usia dibawah 9 tahun dan lansia tidak dizinkan, seiring berjalannya waktu pengecekan kelengkapan kartu identitas tidak lagi dilakukan, hal itu sebatas anjuran bukan peraturan mengikat. Reservasi tiket melalui laman www.ancol.com, pemeriksaan tiket dan suhu tubuh mulai gerbang depan dan pintu masuk.

Penyediaan fasilitas hand sanitizer dan standing banner yang berisikan peraturan protokol kesehatan yang wajib dipatuhi pengunjung. Fasilitas umum seperti tempat duduk, toilet dan tempat ibadah serta beberapa kedai makanan yang buka, sudah memenuhi ketentuan protokol kesehatan yang dipersyaratkan. Terdapat bagian pengawasan yang selalu berkeliling ke seluruh wilayah DUFAN membawa pengeras suara mengingatkan pengunjung akan protokol kesehatan serta bagian desinfeksi lingkungan yang berkeliling ke seluruh wahana permainan menyemprotkan desinfektan sekali dalam sehari. Tidak semua wahana permainan dioperasikan, khususnya wahana indoor. Penerapan protokol kesehatan pada operasional wahana permainan dilakukan dengan baik seperti pada setiap wahana selalu diterapkan jarak antar antrian, ada garis antrian, batas jarak tempat duduk, terdapat petugas yang menyemprotkan hand sanitizer sebelum memasuki area permainan pelaksanaan penerapan protocol kesehatan sudah dilakukan dengan baik oleh karyawan operasional namun terdapat beberapa kendala yang dihadapi.

Terkait permasalahan yang dihadapi yaitu kesadaran pengunjung akan pentingnya menaati protokol kesehatan kapanpun dimanapun di wilayah DUFAN, terdapat pengunjung yang merokok sembarangan, tidak menggunakan masker selama berkegiatan di lingkungan DUFAN, pelanggaran pembatasan jarak dalam antrian. Untuk tanggapan atau persepsi pengunjung yang telah berkunjung di era pandemi COVID-19 cukup baik yang dinilai dari segi sistem pengelolaan operasional, pembelian tiket secara online, informasi protokol kesehatan, protokol kesehatan pengunjung dan petugas wisata, ketersediaan sarana cuci tangan, dan keamanan berwisata di DUFAN. Pengunjung mengharapkan petugas wisata di DUFAN lebih banyak lagi yang berpatroli untuk mengingatkan pengunjung menerapkan protokol kesehatan terutama physical distancing.

\section{DAFTAR PUSTAKA}

ancol.com. (2020). Apa itu aturan Senang Selamat Bareng Bareng \#SSBB? https://www.ancol.com/ssbb

Anggito, A., \& Setiawan, J. (2018). Metodologi penelitian kualitatif. CV Jejak (Jejak Publisher).

cnbcindonesia.com. (2019). BI: Pariwisata Bisa Jadi Penyumbang Devisa Terbesar Kedua. https://www.cnbcindonesia.com/market/20190319084140-17-61460/bi-pariwisatabisa-jadi-penyumbang-devisa-terbesar-kedua

cnnindonesia.com. (2020). Menkeu Ungkap Tiga Sektor yang Paling Cepat Pulih Usai Corona. https://www.cnnindonesia.com/ekonomi/20200417182143-532494674/menkeu-ungkap-tiga-sektor-yang-paling-cepat-pulih-usai-corona

Junaid, I. (2018). Analisis Data Kualitatif Dalam Penelitian Pariwisata. Jurnal Kepariwisataan, 10(01), 59-74. https://doi.org/10.31219/osf.io/npvqu 
Kemenkes. (2020). Permenkes RI KMK No. HK.01.07/MENKES/382/2020. In Peraturan Menteri Kesehatan Republik Indonesia: Vol. Nomor 9 (Issue Pedoman Pembatasan Sosial Berskala Besar dalam Rangka Percepatan Penanganan Corona Virus DIsease 2019 (COVID-19)). http://jurnalrespirologi.org/index.php/jri/article/view/101

Kristina, N. M. R. (2020). Pemulihan Ekonomi Pariwisata Bali di Era New Normal. CULTOURE: Culture Tourism and Religion.

Kusumaningrum, D. A., Hurdawaty, R., \& Yenny, M. (2020). Business Optimism in COVID-19 Pandemic Period in Indonesia. South Asian Journal of Social Studies and Economics, 8(3), 13-22. https://doi.org/10.9734/sajsse/2020/v8i330211

liputan6.com. (2020). Menengok Perjalanan 35 Tahun Dufan Ancol. https://www.liputan6.com/lifestyle/read/4342539/menengok-perjalanan-35-tahundufan-ancol

market.bisnis.com. (2020). Jumlah Pengunjung Anjlok 68 Persen, Kinerja Jaya Ancol (PJAA) Berbalik Rugi. https://market.bisnis.com/read/20200825/192/1282649/jumlahpengunjung-anjlok-68-persen-kinerja-jaya-ancol-pjaa-berbalik-rugi-

megapolitan.kompas.com. (2020). Ada Wisata Virtual di Ancol, Warga Bisa "Jalan-jalan" ke Dufan hingga Seaworld Lewat Ponsel. https://megapolitan.kompas.com/read/2020/12/31/06424341/ada-wisata-virtual-diancol-warga-bisa-jalan-jalan-ke-dufan-hingga

money.kompas.com. (2020). Dampak Pandemi: Indonesia Resesi, Pengangguran Tembus 9,77 Juta. https://money.kompas.com/read/2020/11/06/081247126/dampak-pandemiindonesia-resesi-pengangguran-tembus-977-juta

Munawaroh, S., Murtolo, Ali, S., Budi, Sulistyo, N., Triwahyono, Tugas, \& Adrianto, A. (2018). Peranan Kebudayaan Daerah dalam Perwujudan Masyarakat Industri Pariwisata di Daerah Istimewa Yogyakarta. http://repositori.kemdikbud.go.id/id/eprint/7501

Paramita, I. B. G., \& Putra, I. G. G. P. A. (2020). New Normal Bagi Pariwisata Bali Di Masa Pandemi COVID 19. Pariwisata Budaya: Jurnal Ilmiah Pariwisata Agama Dan Budaya, 5(2), 57-65. https://doi.org/10.36275/mws

Pitana, I. G., \& Diarta, I. K. S. (2009). Pengantar Ilmu Pariwisata. Andi.

Pratisti, W. D., \& Yuwono, S. (2018). Psikologi Eksperimen: Konsep, Teori, dan Aplikasi. Muhammadiyah University Press.

Rachmawati, T. (2017). Metode Pengumpulan Data dalam Penelitian Kualitatif. UNPAR Press.

Simanjuntak, B. A., Tanjung, F., \& Nasution, R. (2018). Sejarah Pariwisata: Menuju Perkembangan Pariwisata Indonesia. Yayasan Pustaka Obor Indonesia.

Suprihatin, W. (2020). Analisis Perilaku Konsumen Wisatawan Era Pandemi Covid-19 ( Studi Kasus Pariwisata di Nusa Tenggara Barat ). Jurnal Bestari, 19, 56-66.

Thoha, M. (2003). Perilaku Organisasi Konsep Dasar dan Aplikasinya. PT. Raja Grafindo Persada.

travel.kompas.com. (2020). Kangen Ancol? Yuk Ikut Tur Virtual di Live Instagram Ancol. 
https://travel.kompas.com/read/2020/05/07/081000927/kangen-ancol-yuk-ikut-turvirtual-di-live-instagram-ancol

UNWTO. (2020). Supporting Jobs and Economies Through Travel \& Tourism. https://www.unwto.org/recommendations-for-recovery-covid-19

Wachyuni, S. S., \& Kusumaningrum, D. A. (2020). The Effect of COVID-19 Pandemic: How are the Future Tourist Behavior? Journal of Education, Society and Behavioural Science, 33(4), 67-76. https://doi.org/10.9734/jesbs/2020/v33i430219

Wahyuningsih, R. (2018). Persepsi pengunjung terhadap fasilitas di objek wisata puncak ulu kasok kabupaten kampar. JOM FISIP, 5(2), 1-13.

WTTC. (2020). Leading Global Protocols for The New Normal.

Yoeti, O. A. (2006). Pariwisata Budaya: Masalah dan Solusinya. Pradnya Paramita. 